\title{
Effect of Crop Establishment Method and Time of Nitrogen Application on the Productivity of Boro Rice in Highland Ecosystem
}

\author{
M. H. Kabir ${ }^{1 *}$, M. S. U. Bhuiya ${ }^{2}$, Nur-E-Elahi ${ }^{1}$ and M. H. Rashid ${ }^{1}$ \\ ${ }^{1}$ Rice Farming Systems Division, Bangladesh Rice Research Institute, Gazipur, Bangladesh \\ ${ }^{2}$ Dept. of Agronomy, Bangladesh Agricultural University, Mymensingh, Bangladesh \\ * Corresponding author
}

Received: 16 October 2007

Accepted: 18 December 2007

\begin{abstract}
An experiment was conducted to study the effect of crop establishment methods and time of nitrogen application in Boro rice at the Bangladesh Rice Research Institute (BRRI) experimental farm, Gazipur during Boro season (2004-05). Five establishment methods viz; line sowing in zero tilled, broadcasting in zero tilled, line sowing in tilled, broadcasting in tilled wet soil and transplanting method and three times of nitrogen application viz; three splits of nitrogen application at 20, 40 and 85 DAS, four splits of nitrogen application at 20,40,60 and 85 DAS and leaf colour chart based nitrogen application methods were investigated. Line sowing in tilled wet soil gave the highest number of tiller $\mathrm{m}^{-2}$, panicles $\mathrm{m}^{-2}$, grains $\mathrm{m}^{-2}$, grain yield, straw yield, gross return, gross margin and less variable cost compared to other direct seeding and transplanting methods. In case of time of nitrogen application, four splits of nitrogen application gave the highest number of tiller $\mathrm{m}^{-2}$, panicles $\mathrm{m}^{-2}$, grains $\mathrm{m}^{-2}$, grain yield, straw yield, gross return, gross margin compared to other nitrogen application techniques.
\end{abstract}

Keywords. Crop establishment method, boro rice, variable cost and time of nitrogen application

\section{Introduction}

Traditional transplanting is a very consuming, water-using, and labourious method of rice cultivation. It consumes more than 30 person $^{-\mathrm{d}}$ $\mathrm{ha}^{-1}$. In Bangladesh, rice production is constrained by higher irrigation and labour costs involved in land preparation, raising of seedlings and transplanting. Direct-Wet-seeding method can help reduce the cost than transplanting. The fields are puddled and sprouted seeds are sown on wet soil by broadcast or line method. Balasubramanian et al. (2002) reported that wet seeding is a common practice in irrigated areas of Asia. Wet-seeded rice in continuous standing water yielded higher than transplanted rice by 3$17 \%$ and increased water use efficiency by $25-48$ $\%$ in the Philippines (Tabbal et al., 2002). Husain et al. (2004) reported that manual direct wet -seeding increased grain yield of Boro rice by about $10 \%$ and reduced growth duration by about 10 days compared with transplanted rice. Socio-economic analysis showed that direct seeded crops incurred about Tk. 2,000/- less costs compared to transplanted crops. 
Among the plant nutrients, nitrogen is the most essential element in determining the yield potential of intensified agricultural systems (Mae, 1997). Rice plants require nitrogen throughout the growth period. A proper timing of $\mathrm{N}$ application, being a precondition for high $\mathrm{N}$ use efficiency which helps reduce losses through ammonia volatilization and de-nitrification. Khan et al. (2004) reported that leaf colour chart (LCC) based $\mathrm{N}$ management produced higher grain yields and reduced fertilizer $\mathrm{N}$ use over farmers' and recommended fertilizer rates in different regions of Bangladesh.

Appropriate crop establishment method and time of nitrogen application are to be established to guide farmers for adoption of the direct seeding technology. Therefore, the study was undertaken to evaluate the performance of different crop establishment methods and to find out the optimum time of nitrogen application in Boro rice under highland ecosystem.

\section{Materials and Methods}

The experiment was conducted at the Bangladesh Rice Research Institute (BRRI) experimental farm, Gazipur during Boro season, 2004-05 in highland ecosystem. Five crop establishment methods viz; line sowing in zero tilled, broadcasting in zero tilled, line sowing in tilled, broadcasting in tilled wet soil and transplanting method with BRRI recommended times of nitrogen application (at 15, 45 and 55 DAT) and three time of nitrogen application viz; three splits of nitrogen application at 20, 40 and 85 DAS, four splits of nitrogen application at 20 , 40, 60 and 85 DAS and leaf colour chart based nitrogen application methods were applied in factorial randomized complete block design (Gomez and Gomez, 1984) with three replications. The size of the unit plot was $5 \times 6$ $\mathrm{m}$. The modern rice variety BRRI dhan 29 was used as the experimental crop. In zero tilled method, the land was soaked for two days and weeds were removed by hand and then the land was leveled by laddering before two days of sowing. In case of tilled method, the land was soaked and three ploughings were done by power tiller followed by two ladderings before two days of sowing. Transplanting was done as usual in puddled soil. $\mathrm{N}, \mathrm{P}_{2} \mathrm{O}_{5}, \mathrm{~K}_{2} \mathrm{O}, \mathrm{S}$ and $\mathrm{Zn}$ were applied at 120, 15, 40, 10 and $2 \mathrm{~kg} \mathrm{ha}^{-1}$ as were urea, triple super phosphate (TSP), muriate of potash (MP), gypsum and zinc sulphate $\left(\mathrm{ZnSO}_{4}\right)$, respectively. The whole amount of TSP, MP, gypsum and $\mathrm{ZnSO}_{4}$ were applied at the time of final land preparation.

Seed rates were $40 \mathrm{~kg} \mathrm{ha}^{-1}$ and $30 \mathrm{~kg} \mathrm{ha}^{-1}$ for direct seeding and transplanting method, respectively. The sprouted seeds were sown in lines by drum seeder in single thin row and broadcast by hand in zero tilled and tilled wet soil. At the same day the sprouted seeds were sown in seedbed for raising seedlings for transplanting method. The spacing " $18 \mathrm{~cm} \mathrm{x}$ continuous" was used in lines by drum seeder and $20 \times 20 \mathrm{~cm}$ spacing were used for transplanting method. Six days after sowing, two inches irrigation was and herbicide (Ronstar) was applied at the rate of one liter ha- ${ }^{-1}$.

The data on tillers $\mathrm{m}^{-2}$, weed density and weed dry biomass, effective tillers $\mathrm{m}^{-2}$ at maturity, plant height, date of maturity, panicles $\mathrm{m}^{-2}$, grains $\mathrm{m}^{-2}$, grain yield, straw yield, cost of land preparation, labour, inputs, irrigation and price of the products and byproducts were recorded. Statistical analysis was done as least significance difference (LSD) using IRRISTAT.

\section{Results and Discussion}

\subsection{Growth parameters, yield and yield components}

\subsubsection{Tillering pattern}

Figure 1 shows that the tiller number in all direct seeding methods was increased up to 100 DAS and thereafter declined quickly up to 115 DAS. In transplanting method (TP), tiller number increased up to 115 DAS. But at maturity differences among direct seeding treatments decreased. It might be due to tillers mortality, intra-plant competition and partial lodging especially in broadcasting in tilled wet soil method (BST). Figure 2 shows that greater tiller production was recorded in BST than in other 
methods at active tillering stage (MATS). Transplanting method produced lower tiller numbers (363). The highest tiller numbers were $623,582,564,561$ and 408 in BST, line sowing in tilled wet soil method (LST), broadcasting in zero tilled wet soil (BSZT), line sowing in zero tilled wet soil (LSZT) and TP, respectively at maximum tillering stage (MTS). Broadcasting in tilled wet soil method also produced higher number of tillers (520) at flower initiation stage (FIS) followed by LST (500) TP produced lower number of tillers (380). Broadcasting in tilled wet soil method produced the higher tiller numbers at MATS, MTS and FIS but at maturity stage (MS), it decreased tremendously and LST method produced higher tiller numbers (462). The total number of tillers in TP did not vary much in most of the growth stages. This was also confirmed by the findings of Utomo et al. (1996). Figure 3 shows that all the nitrogen application treatments except three splits of nitrogen application in transplanting method gave the highest tiller production at $100 \mathrm{DAS}$. Thereafter, tiller production declined up to

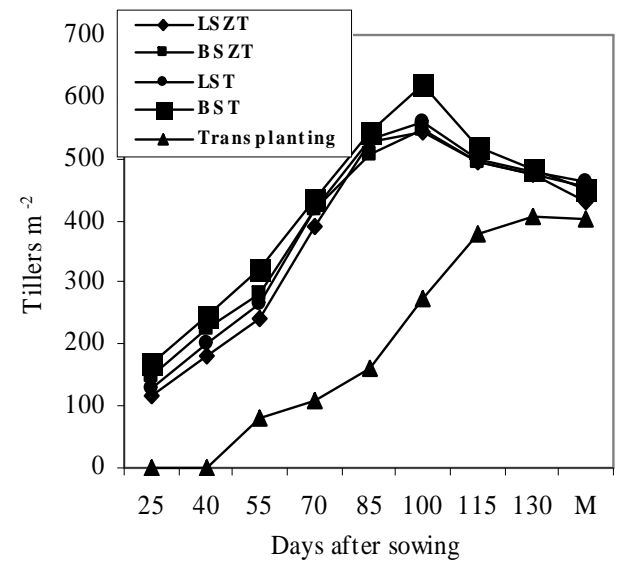

Figure 1. Effect of crop establishment methods on tiller production at different days after sowing of boro rice in high land ecosystem (2004-2005). maturity. Figure 4 shows that at active tillering stage (MATS), leaf colour chart (LCC) based nitrogen application gave higher tiller production and three splits of nitrogen application in transplanting gave the lower number of tillers. The same trend was also found at MTS and flower initiation stage (FIS). But at maturity stage (MS), four splits of nitrogen application gave the higher tiller number which was similar to that of LCC based nitrogen application method.

\subsubsection{Dry matter production}

Figure 5 shows that irrespective of different crop establishment methods dry matter accumulation increased with time and reached maximum at maturity stage. All direct seeding methods produced significantly higher DM than transplanting method (TP) throughout the growing period. Line sowing in tilled wet soil method (LST) produced higher DM throughout the growing period.

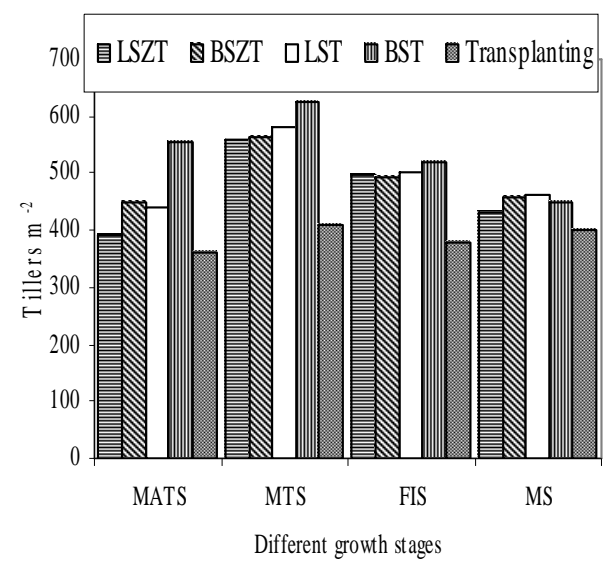

Figure 2. Effect of crop establishment methods on tiller production at different growth stages of boro rice in highland ecosystem (2004-2005). 


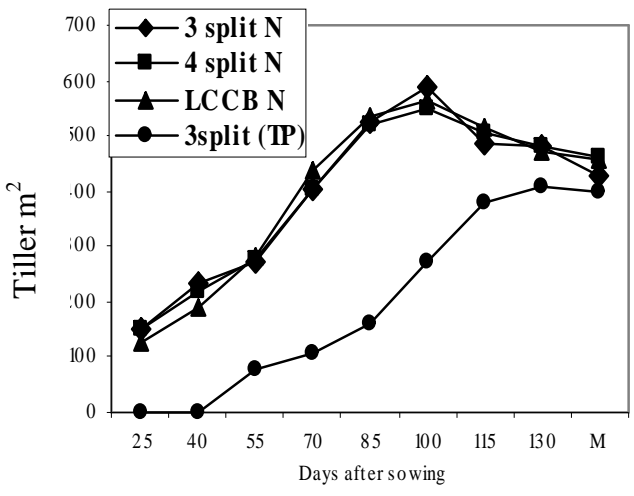

Fig ure 3. Effect of split of nitrogen application on tiller production at different days after sowing of Boro rice in high land ecosystem (2004-2005).

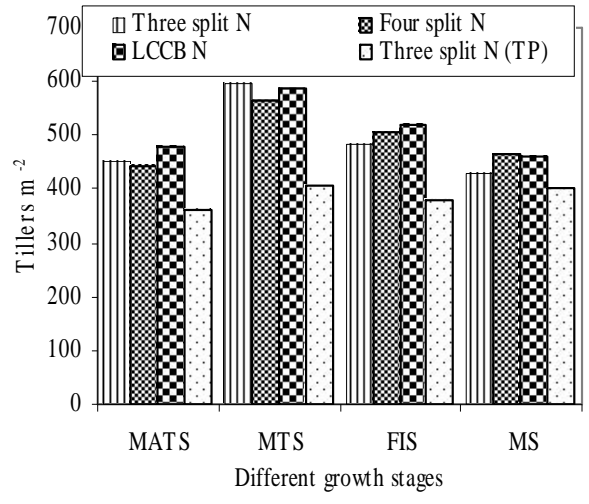

Figure 4. Effect of split of nitrogen application on tiller production at different growth stages of Boro rice in highland ecosystem (2004-2005).

LSZT=Line sowing in zero tilled wet soil, BSZT=Broadcasting in zero tilled wet soil, $\mathrm{LST}=$ Line sowing in tilled wet soil and BST=Broadcasting in tilled wet soil, MATS=Active tillering stage, MTS=Maximum tillering stage, FIS=Flower initioation stage and MS/M=Maturity stage.
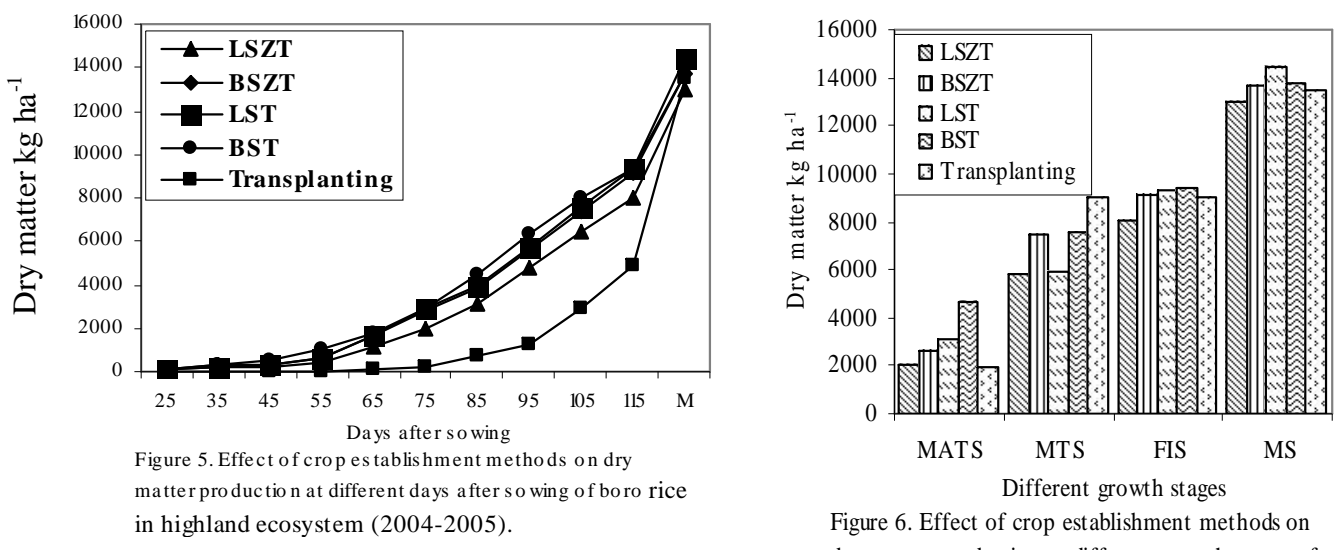

Figure 6. Effect of crop establishment methods on dry matter production at different growth stages of boro rice in highland ecosystem (2004-2005).

LSZT=line sowing in zero tilled wet soil, BSZT=Broadcasting in zero tilled wet soil, LST=Line sowing in tilled wet soil, BST=Broadcasting in tilled wet soil, MATS=Active tillering stage, MTS=Maximum tillering stage, FIS=Flower initiation stage, MS/M=Maturity stage.

In TP, DM production increased very slowly up to 75 DAS. After 85 DAS, DM in TP increased sharply up to 105 DAS. Thereafter DM increased very rapidly up to maturity. Figure 6 shows that at active tillering stage (MATS), DM of broadcasting in tilled wet soil method (BST) was higher and in TP was lower. At maximum tillering stage (MTS), DM in BST was also higher. At flower initiation stage, LST gave higher DM than other methods. As a result, at maturity stage, LST gave higher DM followed by BST. 


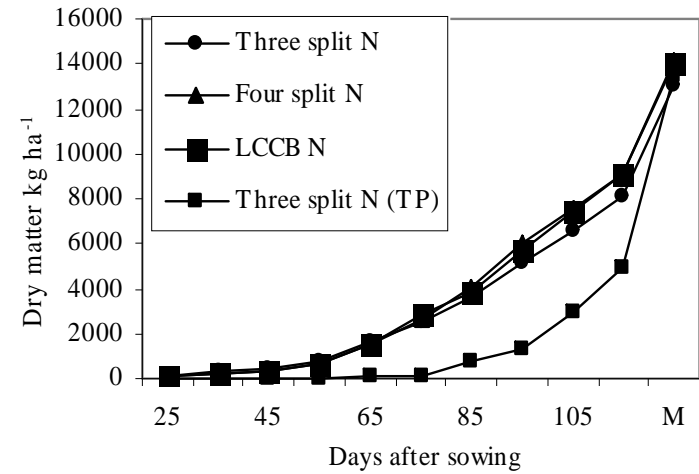

Figure 7. Effect of split of nitrogen application on dry matter production at different days after sowing of Boro rice in highland ecosystem (2004-2005).

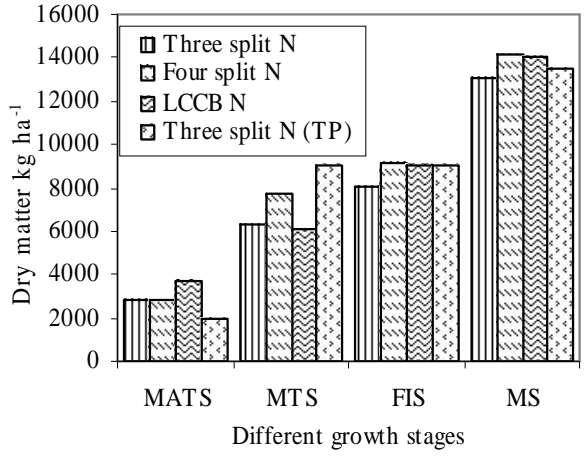

Figure 8. Effect of split of nitrogen application on dry matter production at different growth stages of Boro rice in highland ecosystem (2004-2005).

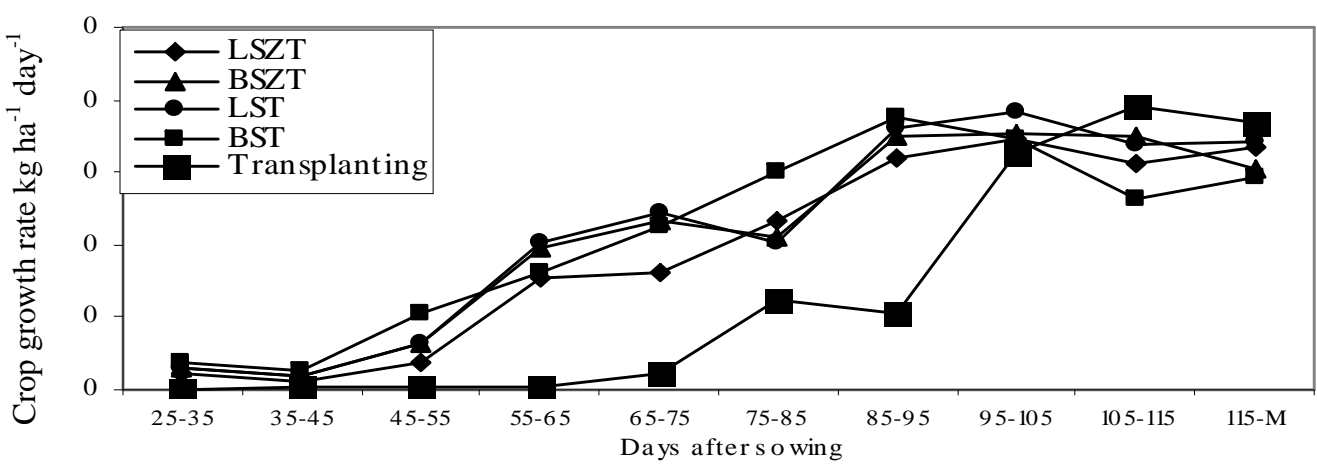

Fig. 9. Effect of crop es tablis hment methods on crop growth rate at different days after sowing of boro rice in highland ecos ys tem (2004-2005).

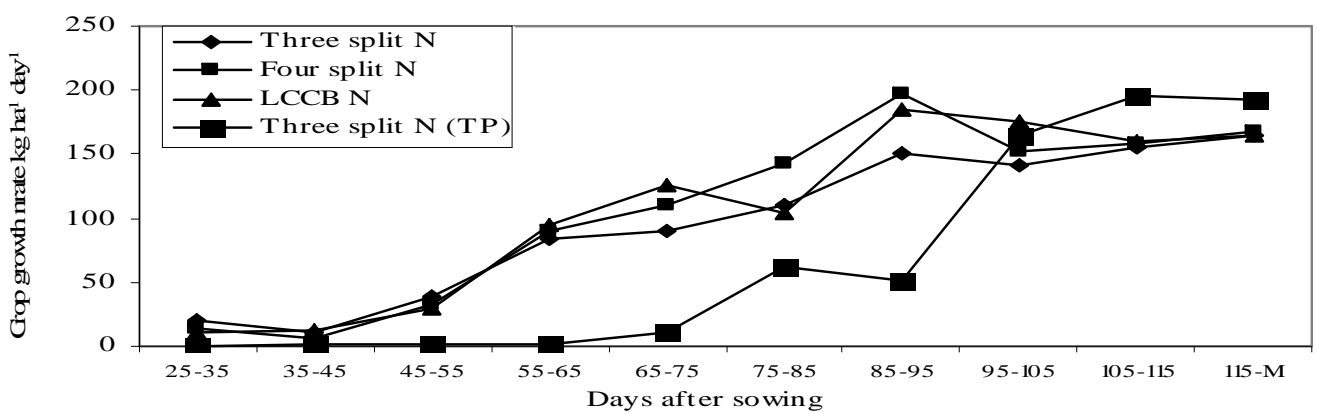

Fig. 10. Effect of splits of nitrogen application on crop growth rate at different days after sowing of Boro rice in highland ecosystem (2004-2005). 
Figure 7 shows that four splits of nitrogen application produced the higher DM accumulation compared to other treatments throughout the growing period. Three splits of nitrogen application in transplanting method (TP) produced lower DM accumulation up to 115 DAS. Thereafter, it increased rapidly up to maturity. Finally, at maturity stage the differences were lower in respect to DM accumulation. Figure 8 shows that at active tillering stage (MATS), DM in LCC based nitrogen application was higher and three splits of nitrogen application in TP was the lower. At maximum tillering stage, DM of three splits nitrogen application in TP at 15, 45 and 55 DAS was higher followed by four splits of nitrogen application compared to other treatments. Because this treatment reached that stage at 130 DAS, whereas the other treatments attained that stage 20 to 30 DAS earlier. At flower initiation stage and maturity stage, four splits of nitrogen application gave higher DM than other treatments.

\subsubsection{Crop growth rate (CGR)}

Figure 9 shows that crop growth rate in all direct seeding methods were higher than transplanting (TP) method from 25 DAS to 105 DAS, thereafter it declined and again inclined up to maturity. CGR increased very slowly up to 75 DAS, then it increased very rapidly up to maturity stage. At maturity stage, TP method showed higher CGR compared to direct seeding. The highest CGR in all direct seeding was achieved at 85 to $95 \mathrm{DAS}$ and in TP, it attained maximum from 105 to 115 DAS. All direct seeding method showed the same CGR trend but in TP it was different. Sharma and Singh (1999) reported similar results. Figure 10 shows that four splits of nitrogen application gave higher CGR compared to other treatments throughout the growing period. Three splits, four splits and LCC based nitrogen application gave more or less similar trend throughout the growing period except three splits of nitrogen application (Transplanting method). The highest CGR of three splits, four splits, LCC based and three splits in transplanting methods were 150,197 , 185 and $196 \mathrm{~kg} \mathrm{ha}^{-1} \mathrm{day}^{-1}$, which were also achieved at 85 to 95,85 to 95,85 to 95 and 105 to $115 \mathrm{DAS}$, respectively.

\subsubsection{Grain production}

Crop establishment methods did not affect grain production (Table 1) statistically. It was found that line sowing in tilled wet soil method gave the higher number of grains $\mathrm{m}^{-2}$. It was observed (Table 2) that four splits of nitrogen application and LCC based nitrogen application were identical and gave the highest number of grains $\mathrm{m}^{-}$ 2 (36520 and 36296). Three splits of nitrogen application produced the lowest number of grains $\mathrm{m}^{-2}$ (33249). This confirms the findings of Bhattacharyya and Singh (1992).

Table 1. Growth parameter, yield and yield components of Boro rice as affected by different crop establishment method in highland ecosystem (2004-2005).

\begin{tabular}{ccccc}
\hline \multirow{2}{*}{ Crop establishment method } & \multicolumn{2}{c}{ Growth parameter, yield and yield components of Boro rice } \\
\cline { 2 - 5 } & $\begin{array}{c}\text { Grains }{ }^{-2} \\
(\text { no. })\end{array}$ & $\begin{array}{c}\text { Growth duration } \\
(\text { days })\end{array}$ & $\begin{array}{c}\text { Grain yield } \\
\left(\mathrm{t} \mathrm{ha}^{-1}\right)\end{array}$ & $\begin{array}{c}\text { Straw yield } \\
\left(\mathrm{t} \mathrm{ha}^{-1}\right)\end{array}$ \\
\hline Line sowing in zero tilled & 35191 & $143.78 \mathrm{~b}$ & $6.77 \mathrm{~b}^{*}$ & $6.26 \mathrm{~b}$ \\
Broadcasting in zero tilled & 35069 & $143.78 \mathrm{~b}$ & $6.85 \mathrm{~b}$ & $6.83 \mathrm{ab}$ \\
Line sowing in tilled & 36772 & $144.22 \mathrm{~b}$ & $7.23 \mathrm{a}$ & $7.24 \mathrm{a}$ \\
Broadcasting in tilled & 34389 & $144.00 \mathrm{~b}$ & $7.01 \mathrm{ab}$ & $6.75 \mathrm{ab}$ \\
Transplanting method & 35903 & $160.00 \mathrm{a}$ & $7.01 \mathrm{ab}$ & $6.51 \mathrm{~b}$ \\
\hline LSD & $\mathrm{ns}$ & 0.41 & 0.32 & 0.57 \\
CV $(\%)$ & 8.4 & 0.3 & 4.7 & 8.7 \\
\hline
\end{tabular}

*Figures in a column having common letter (s) do not differ significantly at $5 \%$ level of significance. 
Table 2. Growth parameter, yield and yield components of Boro rice as affected by different time of nitrogen application in highland ecosystem (2004-2005).

\begin{tabular}{|c|c|c|c|c|}
\hline \multirow[t]{2}{*}{ Time of nitrogen application } & \multicolumn{4}{|c|}{ Growth parameter, yield and yield components of Boro rice } \\
\hline & $\begin{array}{l}\text { Grains } \mathrm{m}^{-2} \\
\text { (no.) }\end{array}$ & $\begin{array}{l}\text { Growth duration } \\
\text { (days) }\end{array}$ & $\begin{array}{l}\text { Grain yield } \\
\left(\mathrm{t} \mathrm{ha}^{-1}\right)\end{array}$ & $\begin{array}{l}\text { Straw yield } \\
\left(\mathrm{t} \mathrm{ha}^{-1}\right)\end{array}$ \\
\hline Three splits (at 20, 40 and 60 DAS) & $33249 \mathrm{~b}$ & $143.92 \mathrm{~b}$ & $6.64 \mathrm{~b}^{*}$ & $6.38 \mathrm{~b}$ \\
\hline $\begin{array}{c}\text { Four splits (at 20, 40, } 60 \text { and } 85 \\
\text { DAS) }\end{array}$ & $36520 \mathrm{a}$ & $144.00 \mathrm{~b}$ & $7.15 \mathrm{a}$ & $7.02 \mathrm{a}$ \\
\hline Leaf colour chart based & 36296 a & $143.92 \mathrm{~b}$ & $7.11 \mathrm{a}$ & $6.90 \mathrm{ab}$ \\
\hline $\begin{array}{l}\text { Three splits for transplanting } \\
\text { (at 20,45 and 55 DAT) }\end{array}$ & 35903 a & $160.00 \mathrm{a}$ & $7.01 \mathrm{a}$ & $6.51 \mathrm{~b}$ \\
\hline LSD & 1734 & 0.36 & 0.28 & 0.50 \\
\hline $\mathrm{CV}(\%)$ & 8.4 & 0.3 & 4.7 & 8.7 \\
\hline
\end{tabular}

*Figures in a column having common letter (s) do not differ significantly at 5\% level of significance.

\subsubsection{Growth duration}

Transplanting method required the longest growth duration (160 days) compared to all direct seeding methods (Table 1). Line sowing in zero tilled and broadcasting in zero tilled wet soil methods were identical and required the shortest growth duration (143.78 days). This was similar to the results reported by Hussain et al. (2003). Three splits nitrogen application in transplanting method required (Table 2) significantly longer growth duration (160 days). Three splits, four splits and LCC based nitrogen application were identical in terms of growth duration.

\subsubsection{Grain yield}

The line sowing in tilled wet soil method produced (Table 1$)$ the highest grain yield $(7.23 \mathrm{t}$ $\mathrm{ha}^{-1}$ ) followed by broadcasting in tilled and transplanting method $\left(7.01 \mathrm{t} \mathrm{ha}^{-1}\right)$. Line sowing in zero tilled wet soil method gave the lowest grain yield $\left(6.77 \mathrm{t} \mathrm{ha}^{-1}\right)$ followed by broadcasting in zero tilled wet soil method $\left(6.85 \mathrm{t} \mathrm{ha}^{-1}\right)$. It might be due to higher panicle, grains, tillers, dry matter, crop growth rate and lower weed infestation in line sowing in tilled wet soil method than in others. This result was confirmed by Bautista and Gagelonia, (1994). Data revealed that four splits of nitrogen application at 20, 40, 60 and 85 DAS method $\left(7.15 \mathrm{t} \mathrm{ha}^{-1}\right)$ and LCC based nitrogen application $\left(7.11 \mathrm{t} \mathrm{ha}^{-1}\right)$ were identical and gave highest grain yield compared to other methods (Table 2). Three splits of (at 20, 40 \& 60 DAS) nitrogen application produced the lowest grain yield $\left(6.64 \mathrm{t} \mathrm{ha}^{-1}\right)$. Bhattacharyya and Singh (1992) reported similar results.

\subsubsection{Straw yield}

Line sowing in tilled wet soil method produced (Table 1) the highest straw yield $\left(7.24 \mathrm{t} \mathrm{ha}^{-1}\right)$. Transplanting method gave the lowest straw yield $\left(6.51 \mathrm{t} \mathrm{ha}^{-1}\right)$. Four splits of (at 20, 40, 60 and 85 DAS) nitrogen application gave (Table 2) the highest straw yield $\left(7.02 \mathrm{t} \mathrm{ha}^{-1}\right)$ followed by LCC based nitrogen application $\left(6.90 \mathrm{t} \mathrm{ha}^{-1}\right)$. Three splits of (at 20, 40 and 60 DAS) nitrogen application gave the lowest straw yield $(6.38 \mathrm{t}$ $\left.\mathrm{ha}^{-1}\right)$.

\subsection{Economic analysis \\ 3.2.1. Variable cost}

The variable cost incurred by transplanting method was (Table 3 ) the highest (31750 Tk ha $\left.{ }^{1}\right)$. The lowest variable cost was incurred by broadcasting in zero tilled wet soil method (30267 Tk ha ${ }^{-1}$ ). This was similar to the results of Balasubramanian et al. (2002). Data revealed that three splits of nitrogen application in transplanting method significantly required (Table 4) the highest variable cost $(31750 \mathrm{Tk}$ $\left.\mathrm{ha}^{-1}\right)$. 
Table 3. Economic analysis of Boro rice as affected by different crop establishment method in highland ecosystem (2004-2005).

\begin{tabular}{lcccc}
\hline \multirow{2}{*}{ Crop establishment method } & \multicolumn{4}{c}{ Economic analysis of Boro rice } \\
\cline { 2 - 5 } & $\begin{array}{c}\text { Variable cost } \\
\left(\text { Tk. ha }^{-1}\right)\end{array}$ & $\begin{array}{c}\text { Gross return } \\
\left(\text { Tk. ha }^{-1}\right)\end{array}$ & $\begin{array}{c}\text { Gross margin } \\
\left(\text { Tk. ha }^{-1}\right)\end{array}$ & BCR \\
\hline Line sowing in zero tilled & $30600.00 \mathrm{~b}$ & $67207.80 \mathrm{~b}$ & 36607.80 & 2.20 \\
Broadcasting in zero tilled & $30266.70 \mathrm{e}$ & $68500.00 \mathrm{ab}$ & 38233.30 & 2.26 \\
Line sowing in tilled & $31366.70 \mathrm{~b}$ & $72316.70 \mathrm{a}$ & 40950.00 & 2.31 \\
Broadcasting in tilled & $31000.00 \mathrm{c}$ & $69815.60 \mathrm{ab}$ & 38815.60 & 2.25 \\
Transplanting method & $31750.00 \mathrm{a}$ & $69630.00 \mathrm{ab}$ & 37880.00 & 2.19 \\
\hline LSD & 45.03 & 3157.23 & $\mathrm{~ns}$ & $\mathrm{~ns}$ \\
CV $(\%)$ & 0.1 & 4.6 & 8.4 & 4.7 \\
\hline
\end{tabular}

*Figures in a column having common letter (s) do not differ significantly at 5\% level of significance.

Table 4. Economic analysis of Boro rice of Boro rice as affected by time of nitrogen application in highland ecosystem (2004-2005).

\begin{tabular}{lcccc}
\hline \multirow{2}{*}{ Time of nitrogen application } & \multicolumn{3}{c}{ Economic analysis of Boro rice } \\
\cline { 2 - 5 } & $\begin{array}{c}\text { Variable cost } \\
\left(\text { Tk. ha }^{-1}\right)\end{array}$ & $\begin{array}{c}\text { Gross return } \\
\left(\text { Tk. ha }^{-1}\right)\end{array}$ & $\begin{array}{c}\text { Gross margin } \\
\left(\text { Tk. ha }^{-1}\right)\end{array}$ & BCR \\
\hline Three splits (at 20, 40 and 60 DAS) & $29883.30 \mathrm{~d}$ & $66121.70 \mathrm{~b}$ & $36238.30 \mathrm{~b}$ & 2.22 \\
Four split (at 20, 40, 60 and 85 DAS) & $31141.70 \mathrm{c}$ & $71360.80 \mathrm{a}$ & $40219.20 \mathrm{a}$ & 2.29 \\
Leaf colour chart based & $31400.00 \mathrm{~b}$ & $70897.50 \mathrm{ab}$ & $39497.50 \mathrm{ab}$ & 2.26 \\
Three splits in transplanting & $31750.00 \mathrm{a}$ & $69630.00 \mathrm{ab}$ & $37880.00 \mathrm{ab}$ & 2.19 \\
(20, 45 \& 55 DAT) & 38.99 & 2734.24 & 2736.69 & $\mathrm{~ns}$ \\
\hline LSD & 0.1 & 4.6 & 8.4 & 4.7 \\
\hline
\end{tabular}

*Figures in a column having common letter (s) do not differ significantly at 5\% level of significance.

Three splits of nitrogen application in direct seeding method needed the lowest variable cost (29883 $\mathrm{Tk} \mathrm{ha}^{-1}$ ) followed by four splits nitrogen application method (31142 $\mathrm{Tk} \mathrm{ha}^{-1}$ ). Four splits and LCC based nitrogen application treatment were statistically identical and required lower variable cost. The similar results were also reported by Khan et al. (2004).

\subsubsection{Gross return}

The gross return obtained (Table 3) from line sowing in tilled wet soil method was the highest (72317 $\mathrm{Tk} \mathrm{ha}^{-1}$ ) followed by broadcasting in tilled wet soil method (69816 $\left.\mathrm{Tk} \mathrm{ha}^{-1}\right)$. Line sowing in zero tilled wet soil method gave the lowest gross return $\left(67208 \mathrm{Tk} \mathrm{ha}^{-1}\right)$. This was confirmed by the findings of Ali (2005). It was observed that four splits of nitrogen application (at 20,40,60 and 85 DAS) method significantly gave (Table 4) the highest gross return (71361 $\mathrm{Tk} \mathrm{ha} \mathrm{h}^{-1}$ ) followed by LCC based nitrogen application method (70898). Three splits of nitrogen application (at 20, 40 and 60 DAS) method gave the lowest gross return (66122 Tk $\left.\mathrm{ha}^{-1}\right)$. These were similar to the findings of Khan et al. (2004). 


\subsubsection{Gross margin}

The highest gross margin was obtained from (Table 3) line sowing in tilled wet soil method $\left(40950 \mathrm{Tk} \mathrm{ha}^{-1}\right)$. Line sowing in zero tilled wet soil method gave the lowest gross margin (36608 Tk ha $\left.{ }^{-1}\right)$. Data revealed that four splits of nitrogen application (at 20, 40, 60 \& 85 DAS) method gave (Table 4) the highest gross margin (40219 Tk ha ${ }^{-1}$ ) followed by LCC based application (39497.50 Tk ha ${ }^{-1}$ ). Three splits of nitrogen application (at 20, 40 and 60 DAS) method gave the lowest gross margin $(36238 \mathrm{Tk}$ $\left.\mathrm{ha}^{-1}\right)$.

\subsubsection{Benefit cost ratio (BCR)}

Crop establishment method and time of nitrogen application had no significant effect on BCR.

\subsection{Interaction effect of crop establishment method and time of nitrogen application}

The interaction effect of crop establishment method and time of nitrogen application was statistically insignificant.

\section{Conclusions}

It was concluded that line sowing in tilled wet soil method gave the highest number of tillers $\mathrm{m}^{-}$ ${ }^{2}$, number of grains $\mathrm{m}^{-2}$, grain and straw yields, gross income and gross margin to other crop establishment methods. In case of time of nitrogen application, four splits of nitrogen application (at 20, 40, 60 and 85 DAS) gave the highest number of tillers $\mathrm{m}^{-2}$, number of grains $\mathrm{m}^{-2}$, grain and straw yields, gross income and gross margin followed by Leaf color chart based (LCC) nitrogen application. So, line sowing in tilled wet soil method with four splits of nitrogen and Leaf color chart (LCC) based nitrogen application may be the best for Boro rice production in highland ecosystem.

\section{References}

Ali, M A. 2005. Productivity and resource-use efficiency of rice as affected by crop establishment and nitrogen management. Ph.D. dissertation (Unpublished), Univ. Philip., Los Baños. Philippines, 182 p.

Balasubramanian, V. and Hill J. E. 2002. Direct seeding of rice in Asia: emerging issues and strategies research needs for the $21^{\text {st }}$ century. In: Pandey, S., M. Mortimer, L. Wade, T.P. Tuong, K. Lopez and B. Hardy (eds.) 2002. Direct seeding: research issues and opportunities. Proceedings of the International Workshop on Direct seeding in Asian Rice Systems: Strategies Issues and Opportunities, 25-28 January 2000, Bangkok, Thailand Los Banos (Philippines): International Rice Research Institute. $383 \mathrm{p}$.

Bautista, E. U. and Gagelonia, E. C. 1994. Rice drum seeder. Technology. Los-Banos. 16 (1): 24.

Bhattacharyya, H. C. and Singh. K. N. 1992. Response of direct seeded rice (Oryza sativa) to level and time of nitrogen application. Indian Journal of Agronomy. 37(4):681-685.

Chowdhury, M. A. H., Talukder, H. H. and Hossain, M. Z. 1995. Effect of Ronstar on weed management, yield and nutrient uptake by rice. Bangladesh Journal of Agricultural Science. 22(I): 93-98.

Gomez, K. A. and Gomez, A. A. 1984. Statistical procedures for agricultural research ( $2^{\text {nd }}$ ed.). International Rice Research Institute, Los Baños, Philippines. p 167.

Husain, M. M., Haque, M. A., Khan, M. A. I., Rashid, M. M. and Islam, M. F. 2003. Direct wet seeded method of establishment of rice under irrigated condition. The Agriculturists. 1(1): 106113.

Husain, M. M., Islam, M. F., Abedin, Z., Rashid, M. M. and Alam, M. Z. 2004. Direct Wet-Seeding using Drum Seeder: A New Dimension in Rice (Oryza sativa L.) cultivation in Bangladesh. The Agriculturists. 2(1): 146-152.

IRRI (International Rice Research Institute). 1988. Annual Report for 1987. International Rice Research Institute, Los Baños, Philippines. 
Khan, A. H., Rashid, H., Mazid, A., Hossain, M., Quddus, A., Alam, A., Buresh, R. J. and Ladha, J. K. 2004. Leaf colour charts for judicious use of nitrogen in Rice. In: Proceedings of Workshop on modern Rice Cultivation in Bangladesh 19-21 April 2004, Gazipur, Bangladesh. Bangladesh Rice Research Institute, 203 p.

Mae, T. 1997. Physiological nitrogen efficiency in rice. Nitrogen utilization photosynthesis and yield potential. In Ando, T.K, Fuji T. Mae, H. Matsumoto, S. Mori and J. Sekiya (eds.) Plant Nutrition for Sustainable Food Production and Environment. Kluwer Academic Publishers. Printed in Japan. pp. 51-60.

Sharma, A. R. and Singh, D. P. 1999. Rice. In Smith, D. L. and Hamel, C. (eds.) Crop yield, Physiology and Process. SpringerVerlag Berlin, Heidelberg, 109-168 pp.

Tabbal, D.F., Bauman, B. A. M., Bhuiyan, S. I., Sibayan, E. B. and Sattar, M. A. 2002. On-farm strategies for reducing water input in irrigated rice; Case studies in the Philippines. Agricultural Water Management, 56: 93-112.

Utomo, W..H., Prastowo, B., Adisarwanto, T., Dacanay, E. V., Kirchhof, G. S. and So, S. B. 1996. Soil puddling and rice growth. In: G.S. Kirchhof and H.B. So (ed.) Management of Clay Soils for Lowland Rice-based Cropping Systems. Australian Centre for International Agricultural Research, Canberra, Australia. ACAIR Proc. 70: 90-94. 